\title{
THE PRICE DETERMINANTS OF WEST TEXAS INTERMEDIATE CRUDE OIL
}

\author{
Abitur Asianto*)1 \\ *) Mercu Buana University \\ Jl. Meruya Selatan No. 1, Kembangan, West Jakarta 11650
}

\begin{abstract}
The crude oil West Texas Intermediate (WTI) price shock affects the international trade as well as the domestic economy of a country and becomes one of the central issues in today's international economic assessment. This study analyzed the determinants of WTI price to predict the percentage price change as result of determinant changes. It employed vector error correction model (VECM) and used the monthly data of WTI price, supply, demand, gold, S\&P 500, T-Note, US dollar index and US GDP from February 1990 to July 2017. Empirical results indicated that WTI supply and demand were the determinants of WTI prices. The supply variable was a major determinant of WTI price. An increase in growth of WTI supply would lead to a decrease in growth of price. On the other hand, an increase in growth of WTI demand would lead to an increase in growth of price.
\end{abstract}

Keywords: crude oil WTI, price determinants, VECM, WTI supply

\begin{abstract}
Abstrak: Guncangan harga minyak mentah West Texas Intermediate (WTI) memengaruhi perdagangan internasional dan juga ekonomi domestik suatu negara dan menjadi salah satu isu sentral dalam pembahasan ekonomi internasional saat ini. Studi ini menganalisis beberapa determinan harga WTI untuk memprediksi perubahan persentase harga sebagai akibat perubahan determinan. Studi ini menggunakan vector error correction model (VECM) dan menggunakan data bulanan harga WTI, supply, demand, emas, S\&P 500, T-Note, indeks dolar AS dan PDB AS dari bulan Februari 1990 sampai Juli 2017. Hasil empiris menunjukkan bahwa supply dan demand WTI adalah faktor determinan dari harga WTI. Variabel supply merupakan determinan utama harga WTI. Kenaikan pertumbuhan supply WTI akan menyebabkan penurunan pertumbuhan harga. Sebaliknya, kenaikan pertumbuhan demand WTI akan menyebabkan kenaikan pertumbuhan harga.
\end{abstract}

Kata kunci: minyak mentah WTI, determinan harga, VECM, supply WTI

\footnotetext{
${ }^{1}$ Corresponding author:

Email: abitursemarang@yahoo.com
}

\section{INTRODUCTION}

According to the Chicago Mercantile Exchange \& Chicago Board of Trade (CME Group), crude oil West Texas Intermediate (WTI) was a light sweet crude oil produced in America and was traded through futures and options. WTI was one of the largest commodities trading in the world. These transactions increase significantly to more than 100,000 contracts per day, today. It showed that WTI commodity was one of the world's macroeconomic indicators (Behmiri and Manso, 2013). WTI influenced the world crude oil price movement comprising of WTI, Brent and Dubai/Oman crude oil significantly and positively, so the WTI price could represent the world crude oil price. The surge and drop in WTI prices could affect the international trade and the domestic economy of the countries. It was necessary to study determinants causing the shocks.

According to the Energy Information Administration (EIA) of US Department of Energy, there were interrelationships among variables namely WTI price, WTI supply, WTI demand, gold prices, S\&P 500 index, 10-Year T-Note, US dollar index, and US GDP variables. This reciprocal relationship was rather difficult to explain by the usual linear equation model. Dynamic models were needed to meet this need. If the variables are time series and stationary at the level, it may use Vector Autoregressive (VAR) method. If the variables are stationary at first difference and co-integrated, it may use the Vector Error Correction Model (VECM) approach (Enders, 2014). 
Various studies analyzing the determinants of crude oil prices have been done by previous researchers. The results were not always mutually supportive each other. Deeper analysis to confirm the results of previous research needs to be done.

Some researchers stated that WTI supply was a major determinant of WTI prices. Baffes et al. (2015) through the SVAR model with monthly supply demand oil data for the 1970-2007 period found that supply changes were more dominant in affecting crude oil prices. Alquist and Kilian (2010) using the VAR-MSPE method found the increasing in uncertainty of supply caused a decrease in spreads of spot and futures oil price.

Other researchers stated that WTI demand was a major determinant of WTI prices. Yin and Zhou (2016) with the GARCH-MIDAS (mixed data sampling) model explained that global demand shocks were the only significant positive determinant in increasing long and short-term oil volatility. Juvenal and Petrella (2014) with the VAR model and dynamic factor model (DFM) using data from 2004-2008 explained that global demand shocks were the biggest determinant of crude oil prices.

Others stated that WTI fundamentals were determinant of WTI prices. Vansteenkiste (2011) with the MarkovSwitching model and using 1992-2011 data mentioned that until 2004, the movement of oil was due to fundamental determinants, but since 2004 the regime has switched to the most prominent chartist regime. Hamilton (2009) using the VAR model explained that oil price shocks were caused by physical supply disruptions, but the 2007-2008 price increase was due to strong demand for stagnant production. Yan (2012) by ECM method explains that each period had different determinants as a driver of crude oil prices.

Other researchers stated that financial markets were also determinant of WTI prices. Büyükşahin and Harris (2011) with the VAR model and using 20002008 data obtained little evidence that hedge funds and noncommercial (speculators) influenced crude oil price changes. Arianto et al. (2010) using the VECM method explains that crude oil has a strong influence on vegetable oils, especially during periods of rising prices. Obadi et al. (2013) also used the VECM method, and concluded that the U.S. dollar exchange rate had an important role in the development of crude oil prices. Dées et al. (2008) using ECM and 20042006 data, explained that supply, demand, refinery utilization, and futures market influenced WTI price in NYMEX. Krichene (2002) using the ECM method and the supply demand data of crude oil and natural gas in the 1918-1999 period has reinforced that the elasticity of commodity prices could explained the market power of oil and volatility in response to price shocks. Gülen and Foss (2012) with the method of event study has created a chart of market mapping affecting oil prices.

This indicated that there were several different research results of the determinants of price of crude oil WTI, so it needed to be analyzed more in-depth in order to analyze the drivers of WTI price. This study is very interesting and becomes one of the central issues of the current international economic studies. This study aimed to examine the determinants of price of crude oil WTI. This study conducted in Jakarta used the monthly data of WTI price, WTI supply, WTI demand, gold price futures, S\&P 500 index, 10-Year T-Note, US dollar index, and US GDP. The data ranged from February 1990 to July 2017. The data were wider than the previous research data, so this supported the novelty of this research. The data were analyzed by VECM approach. The method would analyze the relationship among variables dynamically in the long run, the impulse response function (IRF) and the forecast error variance decomposition (FEVD).

Empirical results indicate that WTI price, WTI supply and WTI demand were the determinants of WTI price. The WTI supply shocks were responded by WTI prices in dominant negative values, while demand shocks were responded by WTI prices in less dominant positive values. An increase in growth of WTI supply will lead to the decrease in growth of WTI price. An increase in growth of WTI demand, will lead to the increase in growth of WTI price.

This study was done to give consideration for economics, trade policy makers, and stakeholders should prioritize the determinants or the drivers of WTI price before implementing policies. Knowing the determinants of WTI price could increase the policies conservatively. This study was expected to advance the science of the financial and investment of commodities, the input for the Otoritas Jasa Keuangan (OJK), and the financial services authority in the development of futures markets in Indonesia. 
The rest of this paper was organized as follows. Next section we explain literature review related determinants of WTI price. In methodology section we explained the data and the VECM approach to co-integration. Finally we presented the findings, discussion and conclusions of the research.

Baye and Prince (2014) stated that the price was determined by the interaction between demand and supply of the market. Demand and supply theory explained events in the marketplace. Market drove the price and quantity to equilibrium levels. Economist Alfred Marshall stated that demand and supply were the forces behind the operation of the market economy. The form of interaction between price and quantity of goods/services was reflected in demand and supply. In the ceteris paribus condition, if demand surged (dropped) and supply dropped (surged), then the price surged (dropped). Excessive prices caused buyers to look for substitution products instead. This condition moved until it reached the equilibrium point where the demand and supply curves intersect. This point indicated a balance of demand and supply (Groenewegen, 2007).

Several studies related to the relationship between variables have also been done by the previous researcher. The VECM has been widely applied in analyzing determinants of price or certain variables, such as the one in Kurniasih et al. (2014). Arianto et al. (2010) using the VECM method explains that crude oil has a strong influence on vegetable oils, especially during periods of rising prices. Ratana et al. (2012) using the VECM method explains that exchange rate movements have no impact on the export volume of Indonesia. Obadi et al. (2013) also used the VECM method, and concluded that the US dollar exchange rate had an important role in the development of crude oil prices. Yan (2012) by ECM method explains that each period had different determinants as a driver of crude oil prices. Dées et al. (2008) using ECM and 2004-2006 data explained that supply, demand, refinery utilization and futures market influenced WTI price in NYMEX. Krichene (2002) using the ECM method and the supply demand data of crude oil and natural gas in the 1918-1999 period has reinforced that the elasticity of commodity prices could explained the market power of oil and volatility in response to price shocks. Gülen and Foss (2012) with the method of event study has created a chart of market mapping affecting oil prices.

\section{METHODS}

According to the Energy Information Administration (EIA), WTI price was affected by the WTI price itself, WTI supply, WTI demand, and financial markets (futures, exchange rate, equity, etc.) as per Figure 1. In this research we used secondary data. We used monthly data of WTI price, supply and demand as an endogenous variables. It also used monthly data of gold commodities price, S\&P 500 index, 10-YearT-Note, US dollar index and US GDP as an exogenous variables. Data ranged from February 1990 to July 2017.

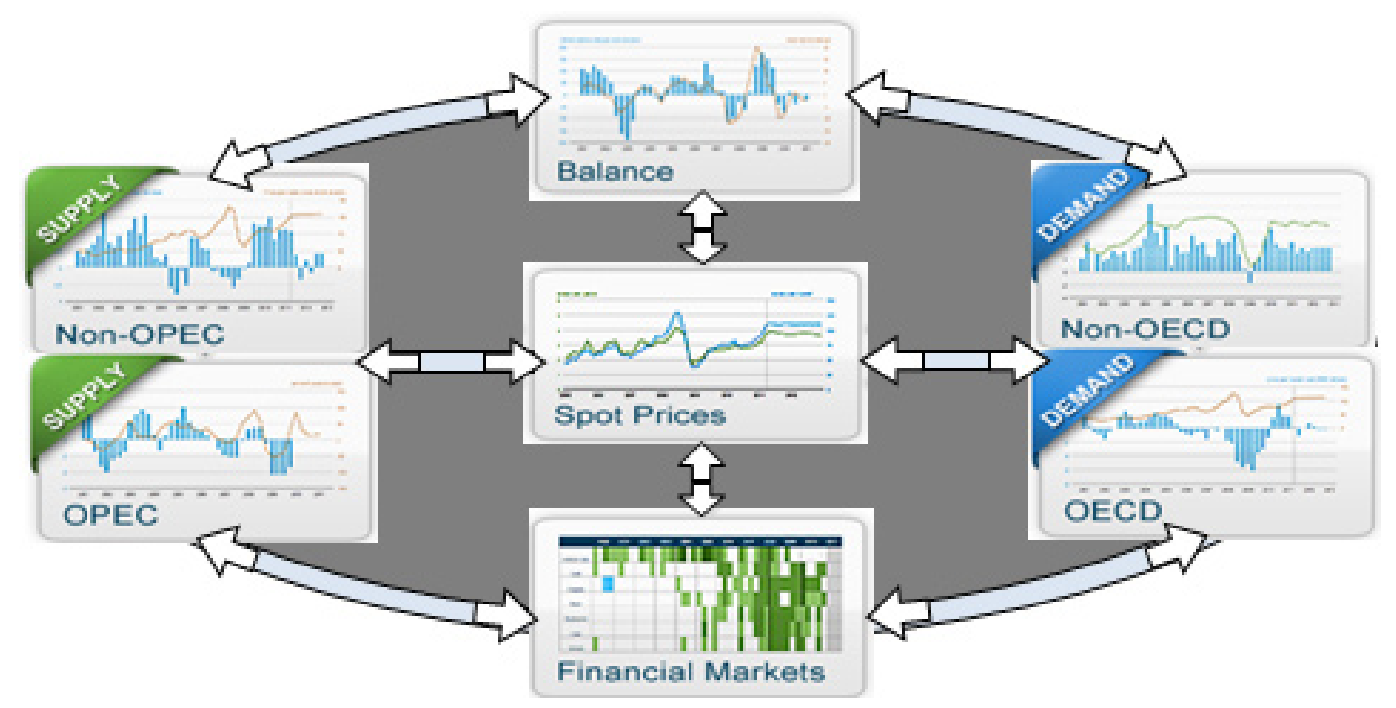

Figure 1. The driver of crude oil WTI (EIA, 2018 (https://www.eia.gov/finance/markets/spot_prices.cfm)) 
WTI was the underlying commodity of the CME Group's oil futures contracts. WTI price was an economic indicator. Gold commodity futures was traded at CME Group through its Commodity Exchange (COMEX) division. According to EIA, gold price was an economic indicator too. The S\&P 500 index futures was an index futures contracts base on S\&P 500 Index value. It was one of the most widely traded. 10-Year T-Note was a 10 -year Treasury note sold by the US government. This value change was a signal of investor confidence. This was used as a proxy for economic financial indicator, such as mortgage rates. The US Dollar Index was a value index of the United States dollar relative to a basket of US trade partner's foreign currencies (EIA, 2018). WTI price, gold price, S\&P 500 index, 10-Year T-Note, US dollar index futures data sources were obtained from www.quandl.com.

US GDP was the gross domestic product of The United States (US). This was one of the primary indicators used to measure the health of US economy. A fluctuation in GDP had a significant effect on the financial market positively (EIA, 2018). US GDP data source were obtained from fred.stlouisfed.org.

WTI supply was the combined of US Field Production of Crude Oil, US Imports of Crude Oil and US Supply Adjustment of Crude Oil. WTI demand was the US crude oil consumption. This was measured from the total of US Refinery and Blender Net Input of Crude Oil and US Exports of Crude Oil (EIA, 2018). The WTI supply and demand data sources were obtained from www.eia.gov.

Interrelation between variables supported by some previous researchers. Ananzeh and Al-Zararee (2016) examine the dynamics relationship between the return of Amman Stock Exchange (ASE) and the price of crude oil and gold for the period span from Jan 1993 to Apr 2016. The main conclusion refer for a Longrun causality running from gold prices and oil prices to Amman Stock Market Returns. Radnia (2014) used time series data of period 1971 to 2010 and used VECM. The oil price had a negative and insignificant relationship with CPI, a positive relationship with exchange rate, and a positive long-run relationships between the CPI and GDP, money supply, interest rate and sanctions. Nazlioglu et al. (2013) used the daily data from 01 January 1986 to 21 March 2011 and used the VAR model. The impulse response analysis indicated that a shock to oil price volatility was transmitted to agricultural markets only in the post-crisis period.

Juanda and Junaidi (2012) expalined that most econometric models of time series were built based on economic theory (structural models) for numerical information analysis and tested existing theories. Economic theory sometimes had not been able to determine the exact specifications for the model because economic theory was sometimes considered complex or because the existing phenomena were perceived to be complex and not adequately explained by existing theories. Relationships among variables sometimes could not be explained through a single static equation model, so it needed to be done through dynamic models that affected each variable. The Vector Autoregressive (VAR) offered an alternative solution for time series data. The data on this model was stationary at the level or called unrestricted VAR (VAR unlimited). This study uses eight variables according to EIA, so the relationship among variables can be explained through the VAR equation (Juanda and Junaidi, 2012). The VAR model of a simple two-variable equation (bivariate) that has a simultaneous causality relationship can be written as follows (Enders, 2014).

$$
\begin{aligned}
& \mathrm{y}_{\mathrm{t}}=\mathrm{b}_{10}-\mathrm{b}_{11} \mathrm{z}_{\mathrm{t}}+\gamma_{11} \mathrm{y}_{\mathrm{t}-1}+\gamma_{12} \mathrm{z}_{\mathrm{t}-1}+\mathrm{e}_{\mathrm{yt}} \ldots \\
& \mathrm{z}_{\mathrm{t}}=\mathrm{b}_{20}-\mathrm{b}_{21} \gamma \mathrm{t}+\gamma_{21} \mathrm{y}_{\mathrm{t}-1}+\gamma_{12} \mathrm{z}_{\mathrm{t}-1}+\mathrm{e}_{\mathrm{zt}} \ldots
\end{aligned}
$$

Variable $y$ and $\mathrm{z}$ influence each other individually in the system. The two equations above could be used as matrix notation as follows.

$$
\begin{gathered}
{\left[\begin{array}{ll}
1 & b_{11} \\
b_{21} & 1
\end{array}\right]\left[\begin{array}{l}
y_{t} \\
z_{t}
\end{array}\right]=\left[\begin{array}{l}
b_{10} \\
b_{20}
\end{array}\right]+\left[\begin{array}{ll}
\gamma_{11} & \gamma_{12} \\
\gamma_{21} & \gamma_{22}
\end{array}\right]\left[\begin{array}{l}
y_{t-1} \\
z_{t-1}
\end{array}\right]+\left[\begin{array}{l}
e_{y t} \\
e_{z t}
\end{array}\right]} \\
\text { В } \quad \mathrm{X}_{\mathrm{t}}
\end{gathered}
$$

or it can be written to be

$$
B X_{t}=\beta_{0}+\beta_{1} X_{t-1}+e_{t} \ldots
$$

If equation 3 was multiplied by B-1 (inverse B) then the equation will be the VAR system in standard form or reduced form as follows.

$$
\mathrm{X}_{\mathrm{t}}=\mathrm{A}_{0}+\mathrm{A}_{1} \mathrm{X}_{\mathrm{t}-1}+\varepsilon_{\mathrm{t}} \ldots
$$

Where: $A_{0}$ is $B^{-1} \beta_{0}$ (intercept), $A_{1}$ is $B^{-1} \beta_{1}$ (vector autoregressive), $\varepsilon_{\mathrm{t}}$ (error). 
Equation 4 shows the existence of a dynamic relationship among variables. Shocks on certain variables can be responded to their impulses against other variables. The weights of contribution among endogenous variables can also be analyzed.

Time series variables are sometimes not stationary at the level but stationary at first difference. Moreover, they are potentially cointegrated. In this condition the model is called restricted VAR. This can also be called Vector Error Correction Model (VECM), so the problem can be solved with VECM model.

This model limits short-term and long-term relationships of endogenous variables into cointegration relationships while considering short-term dynamics. According to Firdaus (2011), the VECM model can be written in the following equation (all variables were in the natural logarithm form).

$$
\Delta \mathrm{y}_{\mathrm{t}}=\mu_{0 \mathrm{x}}+\mu_{1 \mathrm{x}} \mathrm{t}+\Pi_{\mathrm{x}} \mathrm{y}_{\mathrm{t}-1}+\sum_{\mathrm{k}-1}^{\mathrm{i}=1} \Gamma_{\mathrm{ix}} \Delta \mathrm{y}_{\mathrm{t}-1}+\varepsilon_{\mathrm{t}}, \mathrm{t}=1,2, \ldots \ldots
$$

Where: $\Delta y_{t}$ is variable vector $\ln _{-} \mathrm{PCL}_{t}, \ln \mathrm{SCL}_{\mathrm{t}}, \ln$ $\mathrm{DCL}_{\mathrm{t}}, \ln _{-} \mathrm{GC}_{\mathrm{t}}, \ln _{-} \mathrm{SP}_{\mathrm{t}}, \ln _{-} \mathrm{ZN}_{\mathrm{t}}, \ln _{-} \mathrm{ZN}_{\mathrm{t}}, \ln _{-} \mathrm{ZN}_{\mathrm{t}}$, and $\ln _{-}$ $\mathrm{GDP}_{\mathrm{t}} \mu_{0 \mathrm{x}}$ is intercept vector, $\mu_{1 \mathrm{x}}$ is regression coefficient vector. $\mathrm{t}$ is time trend. $\Pi_{x}$ is $\alpha_{x} \beta$ ' where b' contains a long-term cointegration equation. $y_{t-1}$ is variable in level. $\Gamma_{\mathrm{ix}}$ is the regression coefficient matrix. k-1 is a VECM order of VAR. $\varepsilon_{\mathrm{t}}$ is error term.

This research was conducted by hypothesis that WTI supply and WTI demand were the major determinants of WTI price. This hypotheses were taken based on the results of previous research by Baffes et al. (2015), Alquist and Kilian (2010), Hamilton (2009), Vansteenkiste (2011), Yan (2012), Yin and Zhou (2016), and Juvenal and Petrella (2014).

This study was conducted in several stages as follows (1) unit root test using Augmented Dickey Fuller (ADF). If the variables are stationary at the level, then we need to use VAR analysis, (2) VAR stability analysis, (3) Optimal lag analysis, (4) If the variables are stationary at first difference, we will use Johansen's Co-integration analysis. If there is potentially co-integration, we will use VECM approached. If there is no co-integration, it will need a further analysis, (5) next, we analyzed Impulse Response Function (IRF), and (6) Forecast Variance Error Decomposition (FEVD).

\section{RESULTS}

\section{Description of the Development of WTI Price Variable}

WTI prices had surged through 2008 and fell down in 2009. WTI prices had fluctuated until early 2017. During the study period, WTI prices ranged between USD 10.42 to USD 140 per barrel with a standard deviation of 30.18. The highest price of USD 140 per barrel occurred in June 2008. Before performing VECM analysis, it was necessary to test pre estimation using unit root test, VAR stability test and optimal lag test. This test was important because the multivariate time series data generally contained the unit root so that the estimation result became valid (Gujarati and Porter, 2010).

\section{All variables were not stationary at level but stationary at first difference}

First of all, we used the Augmented Dickey Fuller (ADF) test to present the unit root of all variables and the results were presented in Table 1. We found that all variables were not stationary at level but they were stationary at first difference. This showed that there was a relationship of imbalances in the short run. We needed a co-integration test to determine the relationship of balance in the long run.

\section{Optimum VAR Lag was at 13 Lag of 1}

VAR satisfies the stability condition from 1 lag of 1 , up to 31 lag of 1. It meant that the Impulse Response Function (IRF) and Forecast Error Variance Decomposition (FEVD) data would be considered valid. The optimum adjusted $R$ squared showed yields lag 30 of 1 . It showed that the optimum stability condition of VAR was at 30 lag of 1. It was used to find the optimal lag. The AIC model suggested the 13 of 1 value as optimum lag candidate. This test used to remove the autocorrelation problems in VAR systems. The optimal lag was useful for a VAR and co-integration model.

\section{There were 2 Cointegrating Vectors Between All Variables}

Table 2 showed that linear combination of two or more non-stationary variables could produce stationary variables hence called cointegration, so there was a long-term equilibrium relationship among variables. 
It used Johansen's Cointegration Test method. Further analysis using $\lambda \max$ and Trace tests showed that there were two co-integration vectors between all variables. Trace test indicated 2 co-integration equation(s) at the 0.05 level.

\section{WTI Supply and Demand Significantly Affected to WTI Price in the Long Run}

WTI price, demand, and supply were endogenous variables. Gold futures price, S\&P 500 index, 10-year T-Note, US dollar index, and US GDP were exogenous variable. The VECM estimation results are presented in Table 3 and Table 4.

Table 3 shows that in the short run, all variables were significant, but VECM showed that the results have not been stable. It proved that one percent increase in growth of WTI price in lag 1 period resulted in a decrease in growth of price by $-1.85 \%$. Theoretically the price increase leaded to an increase in prices as well. One percent increase in growth of WTI supply in lag 1 period resulted in an increase in growth of price by $2.86 \%$. Theoretically the supply increase leaded to a decrease in prices as well. A one percent increase in growth of WTI demand in lag 1 period resulted in a decrease in growth of price by $-0.99 \%$ in the short run. Theoretically the demand increase leaded to an increase in prices as well. This instability of the results in making the analysis in the short run could not be done directly, it was better to use long-run analysis of VECM.

Table 4 shows that in the long run, WTI prices were significantly influenced by WTI supply and demand variables. A one percent increase in growth of WTI supply in lag 1 period will lead to a decrease in growth of price by $-2.7 \%$. A one percent increase in growth of WTI demand in lag 1 period will lead to an increase in growth of price by $1.18 \%$. VECM analysis in the long run gave the stable results, so it could be concluded that variable supply was the major determinant of WTI price significantly negatively. While the demand variable was the minor determinant of WTI price significantly positively.

Table 1. Augmented dickey fuller (ADF) unit root test analysis

\begin{tabular}{lcccc}
\hline \multirow{2}{*}{ Variable } & \multicolumn{2}{c}{ Level } & \multicolumn{2}{c}{ First difference } \\
\cline { 2 - 5 } & Adj. T-stat//lag lenght & Prob. & Adj. T-stat//lag length & Prob. \\
\hline PCL & $-1.654403 / / 1$ & 0.4536 & $-15.12584 / / 0$ & $0.0000^{*}$ \\
SCL & $-1.332238 / / 13$ & 0.6153 & $-5.006702 / / 12$ & $0.0000^{*}$ \\
DCL & $-1.047805 / / 15$ & 0.7367 & $-15.406046 / / 14$ & $0.0000^{*}$ \\
GC & $-0.798582 / / 11$ & 0.8178 & $-5.469778 / / 10$ & $0.0000^{*}$ \\
SP & $0.020471 / / 1$ & 0.9589 & $-20.43408 / / 0$ & $0.0000^{*}$ \\
ZN & $-1.255648 / / 0$ & 0.6509 & $-17.18255 / / 0$ & $0.0000^{*}$ \\
DX & $-2.387771 / / 3$ & 0.1460 & $-10.59859 / / 2$ & $0.0000^{*}$ \\
GDP & $-1.951476 / / 0$ & 0.3085 & $-16.92008 / / 0$ & $0.0000^{*}$ \\
\hline
\end{tabular}

*) stationary with prob $<5 \%$

Where PCL is Price of crude oil WTI, SCL is Supply of crude oil WTI, DCL is Demand/Consumption of crude oil WTI, GC is Gold futures price, SP is S\&P 500 index futures value, ZN is 10-Year T-Note futures value, DX is US dollar index and GDP is US Gross Domestic Product.

Table 2. Co-integration test analysis

\begin{tabular}{cccccc}
\hline $\begin{array}{c}\text { Hypothesis } \\
\text { Nol }\end{array}$ & $\begin{array}{c}\text { Hypothesis } \\
\text { Alternative }\end{array}$ & Eigenvalue & Trace Statistic & Critical Value & Prob \\
\hline $\mathrm{r}=0$ & $\mathrm{r} \leq 1$ & 0.683582 & 397.8671 & 42.91525 & $0.0001^{*}$ \\
$\mathrm{r}=1$ & $\mathrm{r} \leq 2$ & 0.087893 & 33.09789 & 25.87211 & $0.0053^{*}$ \\
$\mathrm{r}=2$ & $\mathrm{r} \leq 3$ & 0.012335 & 3.934631 & 12.51798 & 0.7516 \\
\hline
\end{tabular}

*) co-integrated variable with prob $<0.05$. Trace test indicated 2 co-integrating eqn (s) at the 0.05 level 
Table 3. VECM in the short run

\begin{tabular}{cccc}
\hline Variable & Coefficient & Standard error & T-statistic \\
\hline CointEq1 & 1.284986 & 0.05526 & $23.2530^{*}$ \\
D(PCL(-1) & -1.848821 & 0.13162 & $-14.0467^{*}$ \\
D(SCL(-1)) & 2.858375 & 0.21282 & $13.4307^{*}$ \\
D(DCL(-1)) & -0.993216 & 0.19949 & $-4.97874^{*}$ \\
GC & 0.758598 & 0.03256 & $23.3007^{*}$ \\
SP & -0.429643 & 0.02335 & $-18.4009^{*}$ \\
ZN & 0.033348 & 0.01164 & $2.86514^{*}$ \\
DX & 0.245226 & 0.07539 & $3.25281^{*}$ \\
GDP & -0.522920 & 0.04558 & $-11.4723^{*}$ \\
C & -13.97622 & 0.76783 & $-18.2023^{*}$ \\
\hline
\end{tabular}

*) significant with T-stat $>$ T-table (1.96)

Table 4. VECM in the long run

\begin{tabular}{cccc}
\hline Variable & Coefficient & Standard error & T-statistic \\
\hline SCL(-1) & -2.697818 & 0.58649 & $-4.59994^{*}$ \\
DCL(-1) & 1.179513 & 0.57907 & $2.03690^{*}$ \\
@TREND(90M01) & 0.001543 & 0.00018 & $8.68689^{*}$ \\
\hline
\end{tabular}

*) significant with T-stat > T-table (1.96); R-squared: 0.738826; adj. R-squared: 0.695457

Where PCL is Price of crude oil WTI, SCL is Supply of crude oil WTI, DCL is Demand/Consumption of crude oil WTI, GC is Gold futures price, SP is S\&P500 index futures value, ZN is 10-Year T-Note futures value, DX is U.S. dollar index and GDP is U.S. Gross Domestic Product.

\section{The WTI Supply Shocks were responded by WTI Price in Dominant Negative Values}

The Impulse Response Function (IRF) is a simulation of the current and future impulse response of a variable due to the shock of another variable. Short-term responses were usually quite significant and tended to change, while long-term responses tended to be consistent. The result showed in Figure 2.

From residual one unit analysis at Figure 2 showed that the WTI price (PCL) shocks were responded by the WTI price (PCL) itself of one unit in the first month, then the response decreased to 0.15 unit at the $3 \mathrm{rd}$ month followed by the fluctuating response until the 57th month and the rest tended to be static relatively at approximate 0.63 unit until the 300th month. This indicated that the current WTI price affected the WTI price itself in the future significantly positively. WTI price shocks had a substantial influence dynamically in the short run then gradually declined toward static in the long run.
The WTI supply (SCL) shocks were not responded by WTI price in the first month, but they were responded in the 15th month by -1.2 unit drop, followed by the fluctuating response until the 100th month, and the rest was static relatively at approximate -0.75 unit. This indicated that the current WTI supply significantly negatively affected the WTI price in the future. WTI supply shocks had a substantial influence dynamically in the short run then gradually declined toward static in the long run.

The WTI demand (DCL) shocks were not responded by WTI price (PCL) in the first month, but they were responded in the 3th month by 0.53 unit decrease, then the response was downward fluctuating until the 100th month, and the rest was relatively static at approximate 0.11 unit. This indicated that the current WTI demand affected the WTI price in the future significantly positively. WTI demand shocks had a substantial influence dynamically in the short run then declined gradually toward static in the long run. 


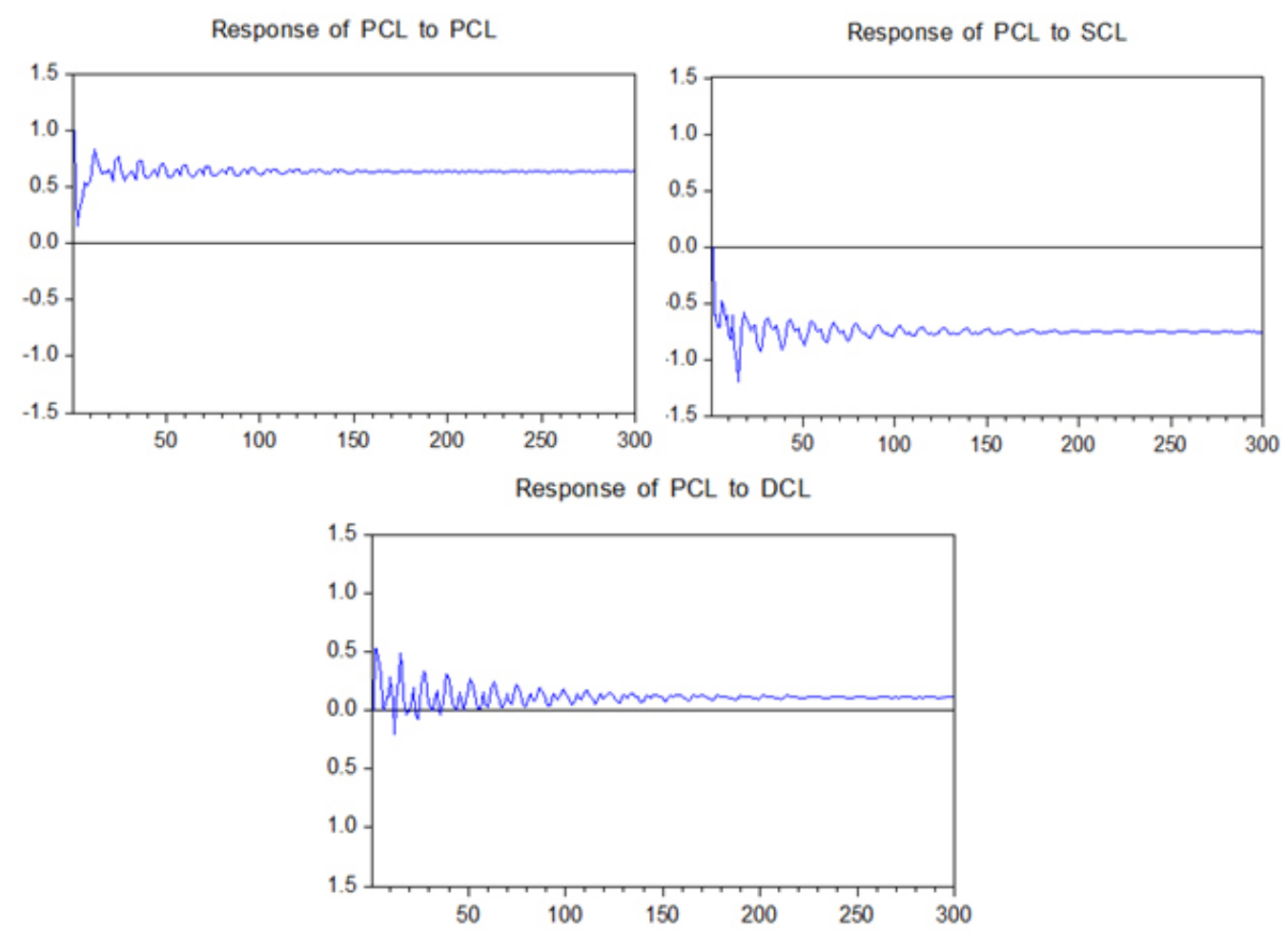

Figure 2. Impulse response function analysis

\section{WTI Supply had a Biggest Contribution to the WTI Price}

The Forecast Error Variance Decomposition (FEVD) analysis aimed to predict the contribution of variance of each variable to the main variable studied in the VAR system. The FEVD pattern showed the multivariate causality properties among the variables in the VAR model. FEVD results showed in Table 5.

Table 5 explained that the contribution of the WTI price (PCL) to price itself was $100 \%$ in the first month, fell to $25.2 \%$ in 30th month, and decreased gradually to 12 percent until 120th month time horizon. The contribution of the WTI supply (SCL) to price surged from 0 to $71.7 \%$ in 30th month, and increased gradually to $86.4 \%$ until 120 th month time horizon. The contribution of the WTI demand (DCL) to price increased from 0 to $3.1 \%$ in 30th month, and decreased gradually to $1.6 \%$ in 120 th month time horizon. The WTI supply was a biggest contribution to the WTI price.

The contribution WTI price, WTI supply and WTI demand to WTI price in the 1 st month were $100 \%$, $0 \%$, and $0 \%$ respectively, then the contribution in 30th month turns to $25.2 \%, 71.7 \%$, and $3.1 \%$ respectively. Subsequently the contribution changed in the 60th month to $16.6 \%, 81.2 \%$, and $2.2 \%$ respectively, and the contribution changed again in the 90th month to $13.6 \%$, $84.6 \%$, and $1.8 \%$ respectively, until the contribution in the 120 th month changed to $12.0 \%, 86.4 \%$, and $1.6 \%$ respectively. The contribution sum of all these variables in each time period was always $100 \%$. The result of this FEVD analysis showed that WTI supply had the dominant contribution to WTI price changes, while the contribution of WTI demand was less dominant in driving WTI price.

\section{Managerial Implication}

These results had important implications for economics and trade policy makers and stakeholders that the WTI supply variable had a dominant role to WTI prices, so it was important to pay attention to the volatility of this variable changes. Demand variable also played a role but it was not very dominant. This study was expected to advance the science of financial and investment of commodities, the input for the Otoritas Jasa Keuangan (OJK), and the financial services authority in the development of futures markets in Indonesia. 


\section{CONCLUSIONS AND RECOMMENDATIONS}

\section{Conclusions}

Empirical results indicate that during the study period, WTI price, WTI supply, and WTI demand as an endogenous variable were the determinants of WTI price influenced to WTI price significantly in the long run. They were instable in the short run. The WTI supply shocks were responded by WTI prices itself in dominant negative values permanently, while WTI demand shocks were permanently responded by WTI prices in less dominant positive values. Increasing growth of supply would lead to decrease in growth of WTI price. On the other hand, increasing growth of WTI demand would lead to increase in growth of WTI price.

\section{Recommendations}

Based on the results of this study, The Energy Administration Information (EIA), OPEC/non-OPEC countries, OECD/non-OECD countries, and the US Government can imply policy through controlling the decreasing (increasing) of WTI inventories in an effort to mitigate risk of spiking (declining) of WTI prices shocks. This study had limited data. Further research could be done with a wider range of data and research in certain periods during a crisis. $\mathrm{R}$ square result showed $74 \%$ value, so it was advisable to add other variable in subsequent research in order to make $\mathrm{R}$ square reach better value.

\section{REFERENCES}

[EIA] Energy Information Administration. 2018. Annual Energy Outlook 2018. Washington: US Department of Energy.

Alquist R, Kilian L. 2010. What do we learn from the price of crude oil futures? Journal of Applied Econometrics 25: 539-573. https://doi. org/10.1002/jae.1159.

Ananzeh IEN, Al-Zararee AN. 2016. Examining the Dynamics Relationship between Gold, Oil prices and Stock Markets: Experience from Jordan Economy. European Journal of Business and Management 8(27): 135-142.

Arianto ME, Daryanto A, Arifin B, Nuryartono N. 2010. Analisis harga minyak sawit, tinjauan kointegrasi harga minyak nabati dan minyak bumi. Jurnal
Manajemen \& Agribisnis 7(1): 1-15.

Baffes J, Kose MA, Ohnsorge F, Stocker M. 2015. The Great plunge in oil prices: causes, consequences, and policy responses. World Bank Group Policy Research Notes No. 1. https://doi.org/10.2139/ ssrn.2624398.

Baye MR, Prince JT. 2014. Managerial Economics and Business Strategy. 8th ed. New York: McGraw Hill.

Behmiri NB, Manso JRP. 2013. Crude oil price forecasting technique: a comprehensive review of a literature. Alternative Investment Analyst Review 2(3): 30-48.

Büyükşahin B, Harris JH. 2011. Do speculators drive crude oil futures prices? The Energy Journal 32(2):167-202.https://doi.org/10.5547/ ISSN0195-6574-EJ-Vo132-No2-7.

Dées S, Gasteuil A, Kaufmann RK, Mann M. 2008. Assessing the factors behind oil price changes. European Central Bank Working Paper Series 855/January 2008. https://doi.org/10.5018/ economics-ejournal.ja.2016-20.

Enders W. 2014. Applied Econometric Time Series. 4th ed. New Jersey: John Wiley and Sons.

Groenewegen P. 2007. Alfred Marshall Economist 1842-1924. New York: Palgrave Macmillan. https://doi.org/10.1057/9780230593060.

Gujarati DN, Porter DC. 2010. Essentials of Econometrics. 4th ed. New York: McGraw-Hill/ Irwin

Gülen G, Foss MM. 2012. Factor impacting oil price. Center For Energy Economics 1-23.

Hamilton JD. 2009. Causes and consequences of the oil shock of 2007-08. NBER Working Paper No. 15002. https://doi.org/10.3386/w15002.

Juanda B, Junaidi. 2012. Ekonometrika Deret Waktu: Teori dan Aplikasi. Bogor: IPB Press.

Juvenal L, Petrella I. 2014. Speculation in the oil market. Journal of Applied Econometric. https:// doi.org/10.1002/jae.2388.

Krichene N. 2002. World crude oil and natural gas: a demand and supply model. Energy Economic 24:557-576.https://doi.org/10.1016/S01409883(02)00061-0.

Kurniasih A, Siregar H, Sembel R, Achsani NA. 2014. The determinant of dividend payout policy in the emerging market of Indonesia: Internal versus external factors. Research Journal of Applied Sciences 9(7): 382-388. doi: 10.3923/rjasci.2014. 382.388 .

Nazlioglu S, Erdem C, Soytas U. 2013. Volatility 
spillover between oil and agricultural commodity markets. Energy Economics 32 (2013): 658-665. https://doi.org/10.1016/j.eneco.2012.11.009.

Obadi SM, Othmanová S, Abdová M. 2013. What are the causes of high crude oil price? causality investigation. International Journal of Energy Economics and Policy 3: 80-92.

Radnia K. 2014. The impacts of oil price and selected macroeconomic variables on consumer price index in IRAN (1971-2010). European Journal of Business and Management 6(2): 154-166.

Ratana DS, Achsani NA, Andati T. 2012. Dampak perubahan nilai tukar mata uang terhadap ekspor Indonesia. Jurnal Manajemen \& Agribisnis 9(3): 154-162.
Vansteenkiste I. 2011. What is driving oil futures prices? fundamentals versus speculation. European Central Bank Working Paper No. 1371.

Yan L. 2012. Analysis of the international oil price fluctuations and its influencing factors. American Journal of Industrial and Business Management 2:39-46. https://doi.org/10.4236/ ajibm.2012.22006.

Yin L, Zhou Y. 2016. What drives long-term oil market volatility? fundamentals versus speculation. Economics: The Open-Accsess, Open-Assessment E-Journal 10(20):1-26. https://doi.org/10.5018/ economics-ejournal.ja.2016-20.

Yu Y. 2014. Did speculation drive oil prices during 2003-2008? [thesis]. Michigan: Michigan Technological University. 